\title{
Pre-harvest sprouting on high-level seed dormancy of bambara groundnut (Vigna subterranea) landraces
}

\author{
MARYATI SARI ${ }^{1,2}$, SATRIYAS ILYAS ${ }^{2, \boldsymbol{v}}$, MOHAMAD RAHMAD SUHARTANTO ${ }^{2}$, ABDUL QADIR \\ ${ }^{1}$ Program of Seed Science and Technology, Faculty of Agriculture, Institut Pertanian Bogor. Jl. Meranti, Bogor 16680, West Java, Indonesia \\ ${ }^{2}$ Department of Agronomy and Horticulture, Faculty of Agriculture, Institut Pertanian Bogor. J1. Meranti, Bogor 16680, West Java, Indonesia. \\ Tel.: +62-251-8629354, Fax.: +62-251-8629352, `email: satriyas252@ gmail.com
}

Manuscript received: 11 August 2021. Revision accepted: 28 November 2021.

\begin{abstract}
Sari M, Ilyas S, Suhartanto MR, Qadir A. 2021. Pre-harvest sprouting on high-level seed dormancy of bambara groundnut (Vigna subterranea) landraces. Biodiversitas 22: 5617-5623. Bambara groundnut (Vigna subterranea (L.) Verdc.) is an underutilized crop. Therefore, its seed quality is not guaranteed. Pre-harvest sprouting (PHS) on bambara groundnut seeds can be found either due to the unpredictable rainfall or the late harvesting and plants are still in the field when rainfall. Conversely, seed dormancy causes a problem for planting. The objective of this research was to identify seed dormancy and PHS of four bambara groundnut landraces and other related seed characters. Four landraces (Madura, Sukabumi, Brown Sumedang and Tasikmalaya) were planted at the end of May 2017. Seeds were harvested at physiological maturity (130 days after planting) during the beginning of the wet season (early October 2017). The result showed that there were variations of PHS among landraces from $1 \%$ to $12 \%$, and variations of seed dormancy rates from $62 \%$ to $82 \%$. There were differences in seed color, seed size, tannin content, seed hardness, and imbibition rate. However, these characters could not clearly explain the diversities in PHS and seed dormancy. There was a high genetic diversity within Tasikmalaya landrace because this landrace had the highest PHS (12\%) and the highest dormancy rate (82\%) as well, although both characters are contradictory. This diversity needs further research, mainly to avoid the disadvantages due to PHS.
\end{abstract}

Keywords: After-ripening, climate change, diversity, germination, hard seed

\section{INTRODUCTION}

Bambara groundnut (Vigna subterranea (L.) Verdc) is an underutilized crop that has the potential as a droughtstress resistant plant (Mayes et al. 2019; Fatimah et al. 2020). Indonesian people usually consume bambara beans as a horticultural product, but it is potential as an alternative staple food and functional food as well. The nutritional content of bambara beans includes carbohydrates $(68.0 \%)$, protein $(17.7 \%)$, fat $(6.6 \%)$, fiber (3.5\%), ash (4.2\%) (Abu-Salem and Abou-Arab 2011), calcium, iron, zinc, magnesium, and manganese (Adelanwa et al. 2017).

The diversity of characters of bambara groundnut in Indonesia has been reported. Manggung et al. (2016) reported that diversity among West Java-Indonesia bambara groundnut landraces as was shown by the time of germination (8.0 - 9.7 days after planting), harvest time (physiological maturity) (112 - 128 days after planting), plant morphology (leaf shapes, plumule color, and petiole color), and seed morphology (testa color). Sobari and Wicaksana (2017) also reported that fresh weight and dry weight of pods, the weight of 100 seeds, and weight seeds per plot were also diverse among landraces.

Seed is a carrier of heredity, including dormancy and pre-harvest sprouting (PHS) characters. Pre-harvest sprouting is disadvantageous for cultivated plants. Rainfall that occurs at the end of seed maturation allows seeds without PHS resistance to sprout in the field before harvesting. Rice (Oryza sativa L.) with higher PHS produced a lower quality of seed (Olaerts and Shon et al. 2014), and PHS on wheat (Triticum aestivum L.) decreased the quality of flour produced (Olaerts and Courtin 2018). The PHS resistance has been reported to be identical with the dormancy character (Mizuno et al. 2018). Thus, dormancy is an important mechanism, not only for species sustainability in the wild environment but also for the successful production of cultivated plants in the wet season. These characters have often been overlooked in many studies. There is a lack of information on these characters, although there are many reports of bambara groundnut diversity. This information is necessary, especially to anticipate unpredictable rainfall due to global climate change. The seed of bambara groundnut develops and matures asynchronously in the soil. Rainfall increases the soil moisture and allows the seed to germinate if it does not have PHS resistance. Many factors can play a role in these characters. Identification of morphology, physical and biochemical characters of the seed are expected to explain the cause of this problem. This research aimed to identify seed dormancy and PHS of four bambara groundnut landraces and to identify the morphological, physical, or biochemical characters related to them. 


\section{MATERIALS AND METHODS}

\section{Plant material}

Four bambara groundnut landraces (Madura landrace, Sukabumi landrace, Brown Sumedang landrace, and Tasikmalaya landrace) were planted at the end of May 2017 and harvested in early October 2017, when the wet season started in Bogor, Indonesia. Each landrace was planted on a $300 \mathrm{~m}^{2}$ plot, contained 12 beds of double row beds with $18 \mathrm{~m}$ length. Spacing within double rows was 0.3 $\mathrm{m}$ apart with $0.4 \mathrm{~m}$ spacing between rows. Each hole was planted one seed. The spacing between one double row and the next double row was $0.8 \mathrm{~m}$. Organic fertilizer of 6 tons manure $\mathrm{ha}^{-1}$ was applied one week before planting. Inorganic fertilizer was given 10 days after planting when the seeds had germinated in the field. The doses were 22.5 $\mathrm{kg} \mathrm{Nha}^{-1}, 36 \mathrm{~kg} \mathrm{P}_{2} \mathrm{O}_{5} \mathrm{ha}^{-1}$, and $45 \mathrm{~kg} \mathrm{~K}_{2} \mathrm{O} \mathrm{ha}^{-1}$.

\section{Observation}

Seed condition on harvested plant

Previous research showed that bambara groundnut seed reached physiological maturity at 125 days after planting (DAP) in Bogor, Indonesia (Ilyas and Sopian 2013). All landraces were harvested at the same time when the plants showed physiological maturity criteria. Harvesting criteria were based on morphological characteristics including yellowing of leaves, most pods had hardened and showed streaks and darker color, seeds also had hardened and were darker in color (Manggung et al. 2016). All landraces had met the harvesting criteria at the same time and the seeds were harvested at $130 \mathrm{DAP}$.

The proportions of mature seeds, PHS seeds, rotten seeds, and immature seeds were observed at the time of harvesting. Each proportion was taken from 10 sample plants.

\section{Dormancy state of freshly mature seed}

The observation was conducted to evaluate the viability of freshly mature seeds. The mature seeds were immediately germinated without the drying process. Seed viability was tested with the sand method at $25{ }^{\circ} \mathrm{C}$. Germination was evaluated until 15 DAP by counting the germination percentage, dormancy intensity (percentage of hard seeds and fresh seeds that did not germinate until 15 DAP), and rotten seed. The observation was conducted in a completely randomized design with four replications, and each replication consisted of 30 seeds. Data were subjected to descriptive analysis.

\section{Observation of seed morphological, physical, and biochemical characters}

The observation of seed characters was conducted using dried seeds. The seeds were dried in the pods under the sun until the moisture content reached $10-11 \%$ (Table 1). The seed morphological observation included seed length and diameter, the weight of 100 seeds, testa and hilum color (according to Royal Horticulture Color Chart), testa thickness (for each landrace, ten seed samples were used with three measurement positions using an Olympus DP25 microscope). The seed's physical character was observed not only on morphological characters but also on seed permeability and seed hardness. The seed permeability was measured through the seed imbibition rate per hour. Seed hardness was measured on ten seeds in each landrace using hardness meter Fujihara Seisakusho, Japan.

Tannin content was measured as the biochemical character, as this component is related to seed physiology. Two grams of twenty mashed seeds were used as a sample and the absorbance value was measured by a spectrophotometer HITACHI U-2010 using $725 \mathrm{~nm}$ wavelength.

\section{Data analysis}

The percentage of PHS and dormant seed is shown in a pie chart for showing the proportion of seeds with preharvest sprouting, mature seed, immature seed, and rotten seed at the time of harvesting; and the proportion of dormant seed, germinated seed, and the rotten seed of the newly harvested seeds. The data of seed size, testa thickness, tannin content, seed hardness, and imbibition rate of seed is presented in a histogram for showing the mean of value as well as the spread of data. The spread of the data was analyzed using descriptive analysis with a standard deviation value.

\section{RESULTS AND DISCUSSION}

\section{Morphological, physical, and biochemical characters}

The result showed some differences in morphological characters on bambara groundnut seeds. Seed morphology of Brown Sumedang landrace had a striking difference from the other three landraces (Madura, Sukabumi, and Tasikmalaya), especially in terms of testa color and seed size. The testa color of Brown Sumedang was dark brown, while that of Sukabumi landrace or Madura landrace was dominated by deep purple or dark purple to black. The testa color of Tasikmalaya landrace was varied, including purplish brown, dark brown, and deep purple (Table 2). Another morphological character that varied among landraces was seed size. Brown Sumedang landrace had the biggest seed size while Madura landrace had the smallest seed size (Figure 1). Similarly, the 100 -seed weight of Brown Sumedang landrace was the highest $(113.40 \mathrm{~g})$ as compared to Madura (94.35 g), Sukabumi (97.56 g), and Tasikmalaya landrace (89.91 g) (Table 3), indicated that Brown Sumedang landrace has the biggest seed than the others.

Table 1. The moisture content of freshly harvested and after dried seeds

\begin{tabular}{lcc}
\hline Landrace & Freshly harvested seeds & Dried seeds \\
\hline & \multicolumn{1}{c}{ Moisture content $(\%)$} \\
Madura & $53.3 \pm 1.0$ & $10.3 \pm 0.2$ \\
Sukabumi & $52.2 \pm 0.7$ & $11.3 \pm 0.3$ \\
Brown Sumedang & $53.9 \pm 0.9$ & $10.7 \pm 0.2$ \\
Tasikmalaya & $53.2 \pm 0.3$ & $11.4 \pm 0.0$ \\
\hline
\end{tabular}


The seed color of bambara groundnut was not related to the testa thickness. The four landraces had no difference in testa thickness (Figure 2A), although Mandizvo and Odindo (2019) reported that seeds with a darker testa color had the thicker testa as compared to those with the lighter testa color. The testa thickness of Madura, Sukabumi, and Tasikmalaya landraces (darker testa color) was not different from that of Brown Sumedang landrace (lighter color). The difference in testa color observed in this research seems to come in line with the difference in tannin content. Brown Sumedang landrace with lighter testa color as compared to the other landraces, had a lower tannin content $(0.73 \%)$ than Madura landrace $(0.90 \%)$, Tasikmalaya $(0,90 \%)$, and Sukabumi landrace (0.83\%) (Figure 2.B).

Table 2. Testa and hilum color of bambara groundnut landraces

\begin{tabular}{lll}
\hline & Testa color ${ }^{1)}$ & Hilum color $^{1)}$ \\
\hline Madura & Black (203A) & White (159D) \\
Sukabumi & Dark Purple (187A), & \\
& Deep Purple (N187A) & White (159D) \\
Brown Sumedang & Dark brown (N172A) & White (159C) \\
Tasikmalaya & Purplish Brown (176B), & White (159D) \\
& Dark Brown (N170A), & \\
& Deep Purple (N187A), & \\
& Blackish Purple (187A) & \\
\hline
\end{tabular}

Number and letter in parentheses are color codes according to Royal Horticulture Color Chart

Table 3. 100-seed weight of bambara groundnut landraces

\begin{tabular}{lc}
\hline Landrace & Weight of $\mathbf{1 0 0}$ seeds $(\mathbf{g})^{\mathbf{1})}$ \\
\hline Madura & $94.35( \pm 8.93)$ \\
Sukabumi & $97.58( \pm 9.12)$ \\
Brown Sumedang & $113.40( \pm 4.73)$ \\
Tasikmalaya & $89.91( \pm 7.35)$ \\
\hline
\end{tabular}

Note: ${ }^{1)}$ Number in parentheses is standard deviation

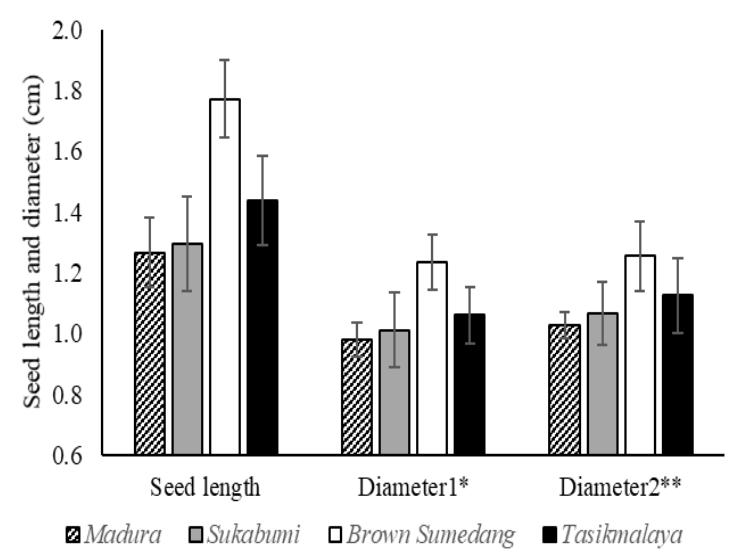

Figure 1. Seed length and diameter of four bambara groundnut landraces. Note: *Diameter 1: diameter from hilum to the backside of the seeds, ${ }^{* *}$ diameter 2 : diameter between two sides of cotyledons
The seeds of Brown Sumedang had the lowest tannin content (Figure 2B). Although nutritional profiling examined in Vigna radiata did not significantly differ from Vigna unguiculata (Enyiukwu et al. 2020). De Almeida et al. (2014) reported no relationship between tannin content and dormancy in sorghum seeds. On the contrary, MacGregor et al. (2015) reported a close relationship between tannin and dormancy in Arabidopsis thaliana L. seeds. Arabidopsis thaliana L. seeds that were ripened at low temperatures experienced an increase in procyanidin (a tannin precursor) content, followed by an increase in dormancy. If seed color indicates the difference in chemical seed content, it can be assumed that there is a correlation between the seed color and seed dormancy.

The highest seed permeability was shown by the Sukabumi landrace; although it was not significant with three other landraces (Figure 2D), this is presumably due to having the lowest hardness among the landraces even though not significant (Figure 2C). There were none of the morphological (testa thickness, Figure 2A), biochemical (tannin content, Figure 2B), and physical factors (seed hardness, Figure 2C) independently indicating the seed permeability. This is understandable because there are various cell structures and biochemical compounds in the testa layers. In legume seeds, the testa generally consists of the waxy compound on its outer layer, a hard layer composed of cellulose and hemicellulose cells, and palisade cells that are secondary walls and contain high tannin and phenolic content (Rangaswamy and Nandakumar 1985), even though there is concentrated lignin in the testa of bambara groundnut (Olaleye et al. (2013).

The imbibition rate was simply predicted by two variables. The high seed hardness $\left(12.3 \mathrm{~kg} \cdot \mathrm{m}^{2}\right)$ supported with high tannin content $(0.9 \%)$ is presumed to cause the lowest rate of imbibition in the Madura landrace $(0.026 \mathrm{~g}$. $\left.10 \mathrm{~g} \mathrm{seeds}^{-1} \mathrm{~h}^{-1}\right)$. The highest rate of imbibition in Sukabumi landrace $\left(0.042 \mathrm{~g}\right.$. $\left.10 \mathrm{~g} \mathrm{seeds}^{-1} \mathrm{~h}^{-1}\right)$ is presumed due to low seed hardness $\left(9.8 \mathrm{~kg} \cdot \mathrm{m}^{2}\right)$ supported with relatively low tannin content $(0.83 \%)$ (Figures $2 \mathrm{~B}, 2 \mathrm{C}, 2 \mathrm{D})$.

\section{Seed dormancy state at harvest time}

Seed dormancy is a mechanism to prevent seed germination in the field before harvesting. Some reports have shown that bambara groundnut seeds have dormancy (Koné et al. 2015; Miya and Modi 2017; Sari et al. 2020). However, the PHS was still found in our current study. All seeds were harvested simultaneously at 130 DAP in early October when the rainy season was started, and this had caused the seeds to be exposed to rain and prone to sprouting. Seed moisture contents at the harvest time were $52-54 \%$ (Table 1). The mechanism of dormancy will play a role and preventing PHS. The result showed that the proportion of PHS was not the same among the four landraces. Brown Sumedang, Sukabumi and Madura landraces had PHS of $1 \%-3 \%$, while Tasikmalaya landrace had the highest PHS (12\%) (Figure 3). High cases of PHS certainly decreased the production potential. The percentage of harvested seed (mature seed) of Tasikmalaya landrace at 130 DAP was the least (56\%) as compared to Madura landrace (61\%), Sukabumi landrace (64\%), and Brown Sumedang landrace (67\%) (Figure 3). 

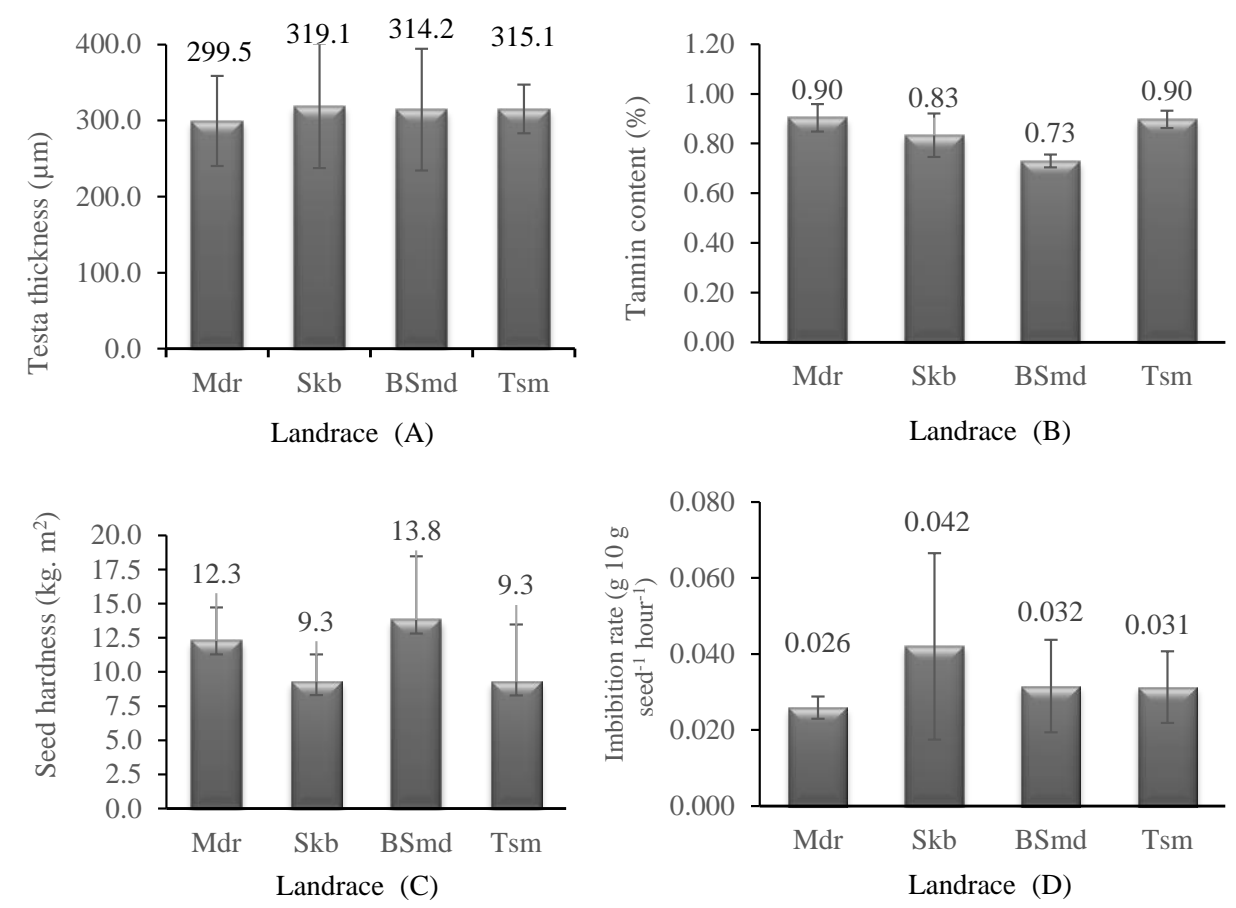

Figure 2. A. Testa thickness, B. tannin content, C. seed hardness, and D. imbibition rate difference of four bambara groundnut landraces._Mdr: Madura, Skb: Sukabumi, BSmd: Brown Sumedang. Tsm: Tasikmalaya

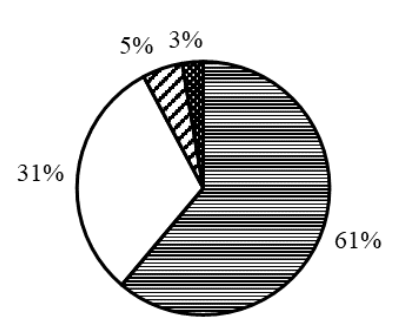

A

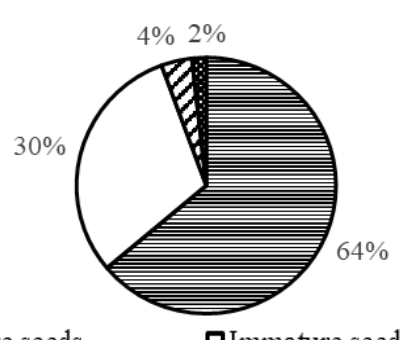

B

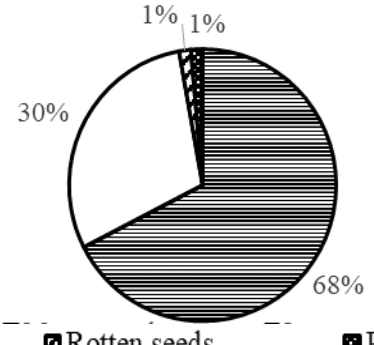

QRotten seeds

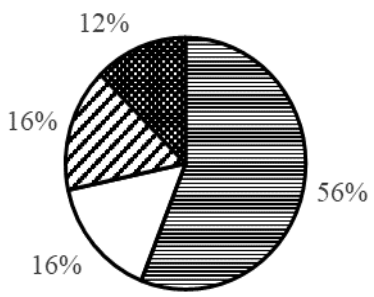

D

Figure 3. The percentage of pre-harvest sprouting of four bambara groundnut landraces at harvest time (130 DAP) in the early rainy season, October 2017. A. Madura, B. Sukabumi, C. Brown Sumedang, D. Tasikmalaya

The disadvantage of PHS is more obvious because it reduces not only production potential but also the quality of seed and food products. According to Olaerts and Courtin (2018), PHS on T. aestivum decreased the quality of flour produced. Shon et al. (2014) also reported that high PHS decreased the quality of rice seed produced. The Hovum cultivar rice seed lot with $8 \%$ PHS (the highest percentage of PHS) had a $30 \%$ lower germination rate as compared to the seed lot with a low PHS (1\%). The lower percentage of germination on the seed lot with a high PHS had the higher fungal infection. The other disadvantage caused by PHS is decreasing desiccation resistance. Soares et al. (2015) reported a loss of desiccation resistance in the imbibed seed of Adenanthera pavonina. Mature dry seed can imbibe water in humid conditions. In seeds without PHS resistance, metabolism of germination may start and the seeds lose their desiccation resistance although they have been harvested and dried.

Bambara groundnut seed has been known to have a dormant character, especially at the early period after harvesting. The evidence of PHS in four landraces of bambara groundnut has added the list of species that have both PHS and dormancy characteristics. Other species with both characters are wheat (Tuttle et al. 2015) and paddy (Shon et al. 2014; Mizuno et al. 2018). Pre-harvest sprouting and dormancy are two contradictory characters; however, Tasikmalaya landrace had the highest PHS (12\%) (Figure 3) and the highest dormancy intensity (82\%) as well (Figure 4). It showed that the Tasikmalaya landrace had a high internal diversity related to dormancy and germination characters. 


\section{Physical and physiological factors of PHS and dormancy state}

There was a similar trend between the imbibition rate and dormancy, but there was a different trend between the imbibition rate and PHS. Imbibition is the first process that initiates germination. The success of imbibition is important in the hard seed dormancy case. Seeds with the highest imbibition rate (Sukabumi landrace) (Figure 5.A) had the lightest dormancy (Figure 5.B), and the deepest dormancy (Tasikmalaya landrace) (Figure 5.B) had a slow imbibition rate (Figure 5.A). This result follows Koné et al. (2015), Miya and Modi (2017) and Sari et al. (2020) reports. Koné et al. (2015) has reported that in vitro germination of whole seeds resulted in slower germination than seeds without testa or embryonic axis of bambara groundnut. According to Miya and Modi (2017), physical and chemical scarification have been reported could increase germination percentage, although reducing seedling vigor in the field.

Pre-harvest sprouting can be caused by failure of producing abscisic acid (ABA). Abscisic acid has a function to prevent germination up to a certain period. Fang and Chu (2008) reported a correlation between ABA losses and the increase of PHS in rice. Imbibition is the first process that initiates germination, but desiccation must have happened before. Kermode et al. (1989) stated that seeds without desiccation would never germinate even though the ABA decreased. This statement indicated that there is an interaction between physiological and physical factors that cause PHS and dormancy.

Hormone content was not observed in this study; however, the pattern of imbibition rate and PHS of four landraces were different (Figures 5.A and 5.C). It indicated that PHS was not only influenced by seed permeability but also by some physiological factors. Fang and Chu (2008) reported that the failure of ABA synthesis causes the PHS. According to Nonogaki et al. (2018), GA and ABA signaling play a role in PHS and GA deactivation rather than ABA biosynthesis.

Sukabumi landrace had the highest permeability, followed by Brown Sumedang, Tasikmalaya, and Madura landraces (Figure 5.A). The highest permeability of the Sukabumi landrace did not cause high PHS (only 3\%) (Figure 5.C). On the contrary, Tasikmalaya landrace had the highest PHS (12\%) (Figure 5.C), although it had a slow imbibition rate relative to Sukabumi and Brown Sumedang landraces (Figure 5.A). In this case, the physiological factors might be more dominant than seed permeability in affecting the PHS. The resistance of PHS is identical with dormancy as revealed by Sari et al. (2020) that the physiological factor is more dominant in controlling germination of bambara groundnut seed at the early period after harvesting, especially when drying has not been completed.

\section{Diversity and its opportunity}

There was a diversity among four bambara groundnut landraces based on seed characters. Brown Sumedang was the landrace with the biggest seed, significantly different from Madura landrace which had the smallest seed (Figure 1). Brown Sumedang landrace had brown testa, significantly different from other landraces, especially Madura and Sukabumi landraces that dominant in deep purple to black, while Tasikmalaya landrace had vary of testa color (Table 2). Brown Sumedang seed had the lowest tannin content, and was significantly different from the others (Figure 2.B).

There was no diversity on testa thickness (Figure 2A), but the Sukabumi landrace had seed permeability (based on imbibition rate) higher than the others. It was significantly different from the Madura landrace, which had the slowest imbibition rate (Figure 2.D). The seeds of Madura and Brown Sumedang landraces were harder relatively than Sukabumi and Tasikmalaya landraces (Figure 2.C). This information complemented the result of previous studies (Manggung et al. 2016; Sobari and Wicaksana 2017) on the bambara groundnut diversity in Indonesia.

Tasikmalaya landrace had the highest PHS (12\%), while the other landraces just had PHS of $1 \%-3 \%$ (Figure 3). Tasikmalaya landrace had the highest seed dormancy intensity (82\%), while the other landraces just had dormancy intensities of $62 \%-73 \%$ (Figure 4). Dormancy is identical to the PHS resistance. Tasikmalaya landrace had the highest of both dormancy and PHS. It means that some seeds in this landrace built the dormancy mechanism effectively and the other seeds failed to build their dormancy mechanism. It is assumed that Tasikmalaya landrace has high genetic diversity within the landrace and has not been cultivated intensively, yet. This landrace has the potential for further genetic exploration.

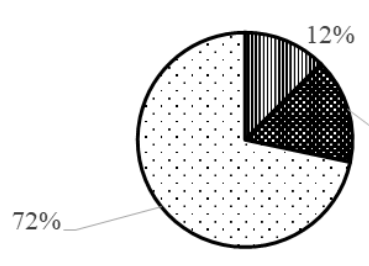

A

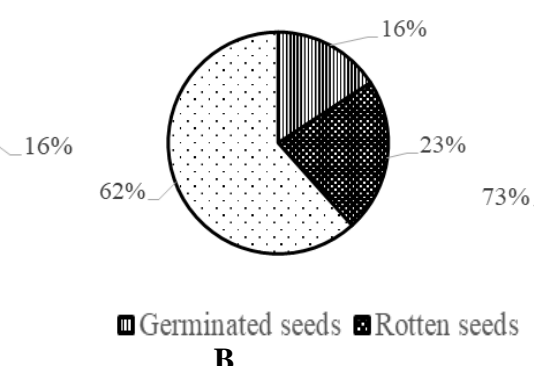

B

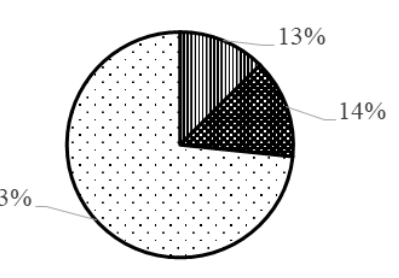

DDormant seeds

C

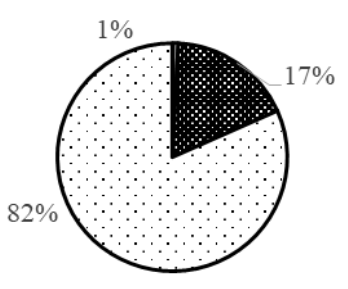

D

Figure 4. The percentage of germinated, rotten, and dormant seeds of freshly mature bambara groundnut seeds. A. Madura, B. Sukabumi, C. Brown Sumedang, D. Tasikmalaya 


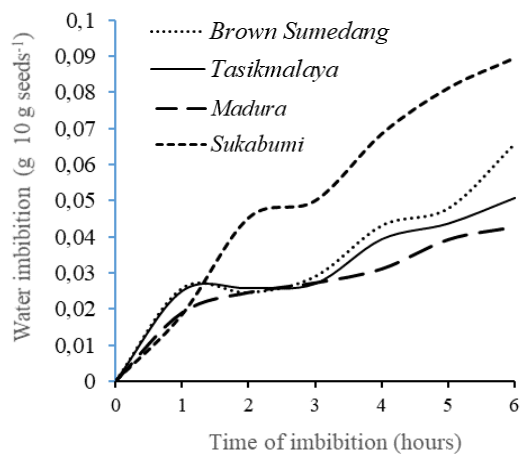

A

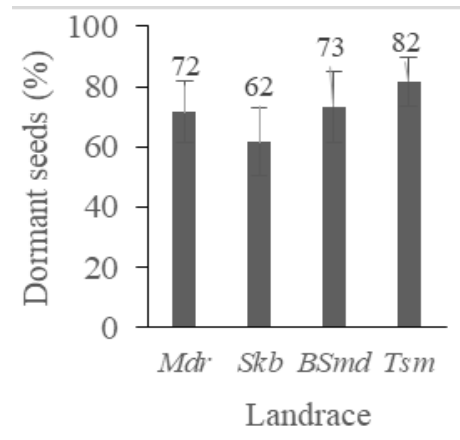

B

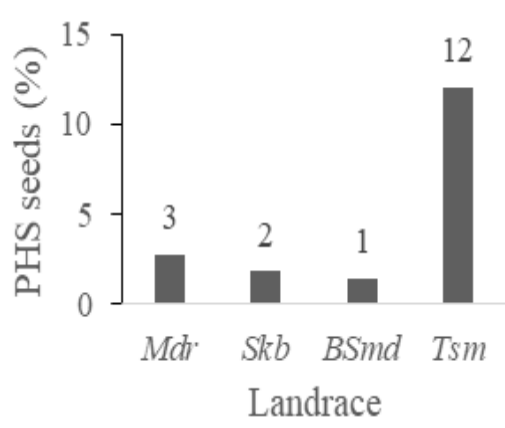

C

Figure 5. A. Imbibition rate, B. dormancy intensity, and C. pre-harvest sprouting of four bambara groundnut landraces. Mdr: Madura, Skb: Sukabumi, BSmd: Brown Sumedang, Tsm: Tasikmalaya

The high PHS that reached $12 \%$ in Tasikmalaya landrace could be a threat to seed and food production. It is suggested that attention needs to be given to PHS as a serious problem. Since the resistance of PHS is indispensable to avoid the reduction of product quality, Mizuno et al. (2018) proposed the insertion of dormancy gene as a strategy to overcome the PHS; however, this project has many difficulties and will need a high cost.

The result of this study showed that Tasikmalaya had the highest PHS (12\%) but it had the highest dormancy intensity $(82 \%)$ as well. Good management in seed production must be driven to obtain moderate dormancy to avoid planting problems and to reduce PHS to avoid decreasing quantity and quality of the product.

In conclusion, there was diversity among four bambara groundnut landraces. Brown Sumedang landrace had significantly different seed morphological characters (testa color and seed size) as compared to the others. Brown Sumedang seed had the size of $113.40 \mathrm{~g}$ per 100 seeds, while the other landraces had the size of $89.91-97.58 \mathrm{~g}$ per 100 seeds. Seed of Brown Sumedang landrace had the lowest tannin content, significantly different from the others. Madura landrace had the smallest seed size with high hardness. Sukabumi landrace had the highest seed permeability and the lowest dormancy intensity. Tasikmalaya landrace had a significantly different level of PHS. It had $12 \%$ PHS, while the others just had 1\% - 3\% PHS. Every landrace showed related unique seed characters.

Levels of dormancy intensity of bambara groundnut seed were similar in pattern to those of imbibition rate, but the seed morphology was not related to imbibition rate (seed permeability). Thus, we could not predict the dormancy intensity by identifying the seed morphology.

As a landrace with a wide internal diversity, the Tasikmalaya landrace requires proper management to maintain its genetic diversity to be explored in further research. Finding the seed dormancy mechanism is needed for the prevention of pre-harvest sprouting without hampering cultivation techniques.

\section{ACKNOWLEDGEMENTS}

The acknowledgment was delivered to the Directorate General of Higher Education, Ministry of Research, Technology and Higher Education, the Republic of Indonesia for funding the research by BPPDN Scholarship scheme.

\section{REFERENCES}

Abu-Salem FM, Abou-Arab AA. 2011. Effect of supplementation of bambara groundnut (Vigna subterranea L.) flour on the quality of biscuits. Afr J Food Sci 5 (7): 376-383. DOI: 10.5897/AJFS.

Adelanwa MA, MIA, Mohammed MS, Esson AE. 2017. Variation in mineral compositions of some bambara groundnut (Vigna subterranea (L.) Verdc.) accessions. Res Sci Technol 9: 06-09. DOI: 10.24831/jai.v48i1.29371.

De Almeida TT, da Rosa SDVF, Oliveira JA, Oliveira AS, da Silva AA, Pereira DS. 2014. Influence of tannin on sorghum seed germination. Afr J Food Sci Technol 5: 136-142. DOI: :10.14303/ajfst.2014.053.

Enyiukwu DN, Chukwu LA, Bassey IN. 2020. Nutrient and anti-nutrient compositions of cowpea (Vigna unguiculata) and mung bean (Vigna radiata) seeds grown in humid Southeast Nigeria: A comparison. Trop Dry 4 (2): 41-45. DOI: 10.13057/tropdrylands/ t040202.

Fang J, Chu C. 2008. Abscisic acid and the pre-harvest sprouting in cereals. Plant Signaling Behav 3 (12): 1046-1048. 10.4161/psb.3.12.6606.

Fatimah, S, Ariffin, Rahmi AN, Kuswanto. 2020. Tolerance and determinants of drought character descriptors of the Madurese landrace bambara groundnut (Vigna subterranea). Biodiversitas 21 (7): 3108-3116. 10.13057/biodiv/d210731.

Ilyas S, Sopian O. 2013. Effect of seed maturity and invigoration on seed viability and vigor, plant growth, and yield of bambara groundnut (Vigna subterranean (L.) Verdcourt). In: Massawe E et al. (eds) Proc. 2nd International Symposium on Underutilized Plants Species "Crops for the Future - Beyond Food Security". Acta Hort 979: 695-702. DOI: 10.17660/ActaHortic.2013.979.78.

Kermode AR, Dumbroff EB, Bewley JD. 1989. The role of maturation drying in the transition from seed development to germination: VII. Effects of partial and complete desiccation on abscisic acid levels and sensitivity in Ricinus communis L. seeds. J Exp Bot 40 (2): 303-313. DOI: $10.1093 / \mathrm{JXB} / 40.2 .303$.

Koné M, Koné T, Silué N, Soumahoro AB, Kouakou TH. 2015. In vitro seeds germination and seedling growth of bambara groundnut (Vigna subterranea (L.) Verdc. (Fabaceae)). Sci World J 2015: 1-8. DOI: $10.1155 / 2015 / 595073$.

MacGregor DR, Kendall SL, Florance H, Fedi F, Moore K. 2015. Seed production temperature regulation of primary dormancy occurs 
through control of seed coat phenylpropanoid metabolism. New Phytol 205 (2): 642-652. DOI: 10.1111/nph.13090.

Mandizvo T, Odindo AO. 2019. Seed coat structural and imbibitional characteristics of dark and light-colored Bambara groundnut (Vigna subterranea L.) landraces. Heliyon 5 (2): p.e01249. DOI 10.1016/j.heliyon.2019.e01249.

Manggung RER. Qadir A, Ilyas S. 2016. Phenology, morphology and yield of four Bambara groundnuts (Vigna subterranea (L.) Verdc.) accession. Jurnal Agronomi Indonesia 44 (1): 47-54. DOI: 10.24831/jai.v44i1.12492. [Indonesian]

Mayes S, Ho WK, Ch-ai HH, Gao X, Kundy AC, Mateva KI, Zahrulakmal M, Hahiree MKIM, Kendabie P, Licea LCS, Massawe F, Mabhaudhi T, Modi AT, Berchie JN, Amoah S. 2019. Bambara groundnut: an exemplar underutilised legume for resilience under climate change. Planta 1-18. DOI: 10.3389/fnut.2020.601496

Miya S, Modi AT. 2017. Overcoming the physical se.ed dormancy in bambara groundnut (Vigna subterranea L.) by scarification: A seed quality study. J Agric Sci Technol B. 7 (2017): 13-24. DOI: 10.17265/2161-6264/2017.01.002.

Mizuno Y, Yamanouchi U, Hoshino T, Nonoue Y, Nagata K, Fukuoka S, Ando T, Yano M, Sugimoto K. 2018. Genetic dissection of preharvest sprouting resistance in an upland rice cultivar. J Breed Sci 68 (2): 200-209 DOI: 10.1270/jsbbs. 17062.

Nonogaki H, Barrero JM, Li C. 2018. Seed dormancy, germination, and pre-harvest sprouting. Front Plant Sci 9: 1783. DOI 10.3389/fpls.2018.01783

Olaerts H, Courtin CM. 2018. Impact of preharvest sprouting on endogenous hydrolases and technological quality of wheat and bread: A Review. Compr Rev Food Sci Food Saf 17 (3): 6 98-713. DOI: $10.1111 / 1541-4337.12347$
Olaleye AA, Adeyeye EI, Adesina AJ. 2013. Chemical composition of bambara groundnut (V. subterranea L. Verdc) seed parts. Bangladesh J Sci Ind Res 48 (3): 167-178. DOI: 10.3329/bjsir.v48i3.17325.

Ran X, Wan H, Li J, Liang Y, Xu J. 2015. An Investigation of the relationship between lignin content and seed coat traits in yellowseeded Brassica napus L. Acad J Agric Res 3 (1): 1-8.

Rangaswamy NS, Nandakumar L. 1985. Correlative studies on seed coat structure, chemical composition, and impermeability in the legume Rhynchosia minima. Bot Gaz 146 (4): 501-509. DOI: 10.1086/337555 Sari M, Ilyas S, Suhartanto MR, Qadir A. 2020. Changes in dormancy behaviour during the desiccation process of bambara groundnut (Vigna subterranean L. Verdc.) seeds. J Agron Indones 48 (1): 37-43. DOI: 10.24831/jai.v48i1.29371.

Shon J, Kim J, Jung H, Kim BK, Choi KJ, Yang W. 2014 Effect of preharvest sprouting on seed viability, germination and seedling emergence rate of rice. J Crop Sci 59 (4): 427-434. DOI: 10.7740/kjcs.2014.59.4.427

Soares G, Dias DC, Faria JM, Borges EE. 2015. Physiological and biochemical changes during the loss of desiccation tolerance in germinating Adenanthera pavonina L. seeds. Anais da Academia Brasileira de Ciências 87: 2001-2011. DOI: 10.1590/00013765201520140195.

Sobari E, Wicaksana N. 2017. Genetic diversity and relationship of bambara groundnut (Vigna subterranean L.) genotype landraces of West Java. Jurnal Agro 4 (2): 90-96. DOI: 10.15575/biodjati.v6i1.6538. [Indonesian]

Tuttle KM, Martinez SA, Schramm EC, Takebayashi Y, Seo M, Steber CM. 2015. Grain dormancy loss is associated with changes in ABA and GA sensitivity and hormone accumulation in bread wheat, Triticum aestivum (L.). Seed Sci Res 25 (2): 179-193. DOI: $10.1017 /$ S0960258515000057. 